\title{
New Records of Apodemus microps Kratochvíl et Rosicky, 1952 from Poland
}

Nowe stanowiska Apodemus microps Kratochvíl et Rosicky, 1952 z terenu Polski

\author{
Zygmunt NIKODEM \& Andrzej L. RUPRECHT
}

\begin{abstract}
Nikodem Z. \& Ruprecht A. L., 1976: New record of Apodemus microps Kratochvíl et Rosicky, 1952 from Poland. Acta theriol., 21, 11: 174-175. [With 1 Table].

The authors document five new distribution localities for Apodemus microps in Lublin province. Apodemus microps occurs with Apodemus flavicollis and Apodemus sylvaticus. Some skull dimensions are given. [Mammals Res. Inst., Polish Acad. Sci., 17-230 Białowieża].
\end{abstract}

This species is known only from several localities in lower Silesia $(\mathrm{H} \mathrm{u}-$ miński, 1964; Chudoba \& H u miński, 1974) and Pieniny Mts ( $\mathrm{H}$ a i t ling e r, 1972). During examination of skeletal remains in Barn owl pellets ( $\mathrm{Nikodem}$, msc) from Lublin province we found rostral parts of skulls of the mouse subgenus Sylvaemus O g n e v \& V or o b i e v, 1923, a small-bodied but distinct group. Determinations made by one of

\section{Table 1}

Skull dimensions of Apodemus microps found in Barn owl pellets from Lublin Palatinate (Poland).

\begin{tabular}{|c|c|c|c|c|c|c|}
\hline $\begin{array}{l}\text { Nos coll. } \\
\text { of MRI }\end{array}$ & Date & Locality & $\begin{array}{l}\text { Age } \\
\text { class }\end{array}$ & $\begin{array}{r}\text { Length of } \\
\text { For, incisiva }\end{array}$ & $\begin{array}{l}\text { Breadth } \\
\text { cf } M^{1} \\
\text { crown }\end{array}$ & $\begin{array}{l}\text { Maxillary } \\
\text { tooth-row } \\
\text { length }\end{array}$ \\
\hline 245 & 26.X.1964 & $\begin{array}{c}\text { Żulice, } \\
50^{\circ} 32^{\prime} \mathrm{N}, 23^{\circ} 49^{\prime} \mathrm{E}\end{array}$ & IV & 4.67 & 1.00 & 3.46 \\
\hline 245 & & & II & - & 1.01 & 3.40 \\
\hline 274 & 3.IX.1964 & $\begin{array}{c}\text { Frampol } \\
50^{\circ} 41^{\prime} \mathrm{N}, 22^{\circ} 41^{\prime} \mathrm{E}\end{array}$ & III & - & 1.04 & 3.28 \\
\hline 375 & 26.VIII. 1960 & $\begin{array}{c}\text { Euszczów } \\
51^{\circ} 19^{\prime} \mathrm{N}, 22^{\circ} 44^{\prime} \mathrm{E}\end{array}$ & III & 4.07 & 1.03 & 3.41 \\
\hline 779 & 8.V.1962 & $\begin{array}{c}\text { Lublin } \\
51^{\circ} 15^{\prime} \mathrm{N}, 22^{\circ} 34^{\prime} \mathrm{E}\end{array}$ & IV & 4.45 & 1.02 & 3.29 \\
\hline 784 & 29.IX.1962 & " & IV & - & 1.04 & 3.40 \\
\hline 789 & 12.XII.1963 & & II & - & 1.09 & 3.37 \\
\hline 815 & 29.VIII.1961 & $\begin{array}{c}\text { Markuszów } \\
51^{\circ} 23^{\prime} \mathrm{N}, 22^{\circ} 16^{\prime} \mathrm{E}\end{array}$ & III & 4.34 & 1.08 & 3,48 \\
\hline 816 & 27.IX.1962 & " & III & 4.57 & 1.06 & 3.30 \\
\hline
\end{tabular}

us (A. R.) and based on breadth of $M^{1}$ crown and length of the upper tooth row (cf. Haitling e r \& $\mathrm{Ruprecht}$, 1967) indicated that the material was definitely Apodemus microps $\mathrm{Kr}$ a to c hvíl \& $\mathrm{Rosicky}$, $1952^{1}$. The measurements (Table 1 ) show that the range in variation of Apodemus microps skull elements from Lublin province is the same as from populations from Wrocław and Czechoslovakia ( $\mathrm{H}$ a i t ling e r \&

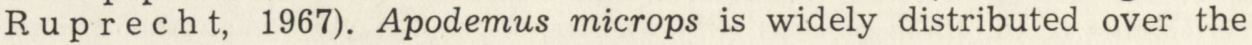

1 The authors gratefully acknowledge the assistance of Dr. H. S t e in e r, Vienna, in verifing the identity of the skull elements. 
Lublin province and is, moreover, sympatric with Apodemus flavicollis (M e lc hi or, 1834) and Apodemus sylvaticus ( $\mathrm{L}$ i n $\mathrm{n}$ a e u s, 1758). We conclude that Apodemus microps is more widely distributed over southern Poland than formely thought, and suspect that as additional data accumulate, this species may be shown to have an even greater range extension.

\section{REFERENCES}

Chudoba S. \& Humiński S., 1974: Gryzonie-szkodniki w obrębie jednego dużego gospodarstwa rolnego. Zesz. Nauk. Akad. roln. Wrocław 104, [1973], Zootechn., 19: 221-227. Haitlinger R., 1972: Apodemus microps K ratochvíl \& Rosicky, 1952, w Polsce. Przegl. zool., 16: 68-74. Haitlinger R. \& Ruprecht A. L., 1967: The taxonomic value of teeth measurements in the subgenus Sylvaemus Ognev \& Vorobiev, 1923. Acta theriol., 12: 180-187. H u m iński S., 1964: Nowy ssak w faunie Polski - Apodemus microps Kratoch víl et Rosicky, 1952. Acta theriol., 9: 387-389. Nikodem Z., 1974: Badania nad fauną drobnych ssaków Lubelszczyzny w aspekcie sezonowym na podstawie analizy zrzutek sów. Ph. D. Thesis: $1-91$, Agricult. Acad., Wrocław.

Accepted, July 16, 1975. 